\title{
The effects of ammonium on growth, accumulation of free amino acids and nutritional status of young phosphorus deficient Stratiotes aloides plants
}

\author{
A.J.P. Smolders, C. den Hartog, C.B.L. van Gestel, \\ J.G.M. Roelofs \\ Department of Ecology, Research Group Environmental Biology, University of Nimegen. Toernooiveld, $N L$ \\ 6525 ED, Nijmegen, The Netherlands
}

\begin{abstract}
Turions of Stratiotes aloides L. were grown at different ammonium levels under phosphorus deficient conditions in a staged gradient. After 13 weeks the plantlets appeared to be severely phosphorus deficient with the growth being seriously impaired. Nitrogen in the plants appeared to be predominantly present as soluble amino acids. This indicates that net protein synthesis was seriously disturbed. Asparagine was by far the dominant soluble amino acid in the plantlets. At the highest external ammonium levels, net growth was significantly retarded when compared with the other concentrations with free ammonium accumulating in the plants. Ammonium uptake under phosphorus deficient conditions strongly increases nutrient imbalances in the plants, and thus their vitality.
\end{abstract}

Keywords: Ammonium toxicity; Amino acid accumulation; Asparagine; Phosphorus deficiency; Stratiotes aloides

\section{Introduction}

In general, free ammonium can inhibit respiration and photo- phosphorylation (Vines and Wedding, 1960) and thus can become toxic when it accumulates in plant cells. To prevent ammonium toxicity, many (land) plants respond to a strongly increased availability of ammonium by the synthesis of specific amino acids and amines, particularly those with a high $\mathrm{N}: \mathrm{C}$ ratio (Marschner, 1986). Arginine ( $\mathrm{N}: \mathrm{C}$ ratio 0.66$)$, for instance,

\footnotetext{
* Corresponding author.
} 
is found to accumulate in different pine tree species (Van Dijk and Roelofs, 1988; Näsholm and Ericsson, 1990; Ericsson et al., 1993; Näsholm et al., 1994). Asparagine $(\mathrm{N}: \mathrm{C}$ ratio 0.50$)$ and glutamine $(\mathrm{N}: \mathrm{C}$ ratio 0.40$)$ are also well known to accumulate in many different species (such as tomato, apple, barley and pea) when exogenous ammonium levels are increased (Webster, 1959; Tromp and Ovaa, 1979; Magelhaes and Wilcox, 1984; Rotsnitschek-Schimmel, 1985).

Increased synthesis of specific amino acids can also be caused by nutrient deficiencies (Lorentz, 1975; Magelhaes and Wilcox, 1984; Rabe and Lovatt, 1986; Rabe, 1990; Ericsson et al., 1993), probably because nutrient deficiencies can lead to a relative surplus of nitrogen. Although the detoxification of ammonia costs energy and carbohydrates the accumulation of specific amino acids is rarely inhibited. This is probably due to the high toxicity of ammonium which results in plants avoiding its accumulation at any cost (Rabe and Lovatt, 1986; Rabe, 1990).

There is not a great deal of information about the effects of elevated ammonium levels in the water layer on aquatic macrophytes. In this article we present the results of an experiment with young plants of Stratiotes aloides L. growing in a staged ammonium gradient under phosphorus deficient conditions. Stratiotes aloides is an aquatic macrophyte which mainly reproduces asexually by means of turions and tillers. The species is only found in slightly eutrophic waters and seldom in waters in which phosphate levels are lower than approximately $1 \mu \mathrm{mol} \mathrm{1}^{-1}$ (De Lyon and Roelofs, 1986). Stratiotes is also not found in waters with raised ammonium levels (De Lyon and Roelofs, 1986; A.J.P. Smolders, unpublished data, 1993). In order to gain insight in the mechanism involved in the decline of young plantlets at relatively high ammonium levels under phosphate deficient conditions, phosphate in the nutrient solutions was maintained at low levels in the experiment. Young Stratiotes plants, not yet rooted, may be exposed to such conditions in the field.

\section{Materials and methods}

\subsection{Plant material}

Turions (fresh weight about $2 \mathrm{~g}$ ) of $S$. aloides were collected in a stand in the neighbourhood of the village of Zegveld (The Netherlands) in April 1994. Nine of these turions were dried and analysed as described below. The remaining ones were used in the experiment.

\subsection{Culture conditions}

The turions were placed in glass containers (filled with nutrient solutions), which were then placed in a stainless steel water bath. The water bath was maintained at $18^{\circ} \mathrm{C}$ by means of a Neslab type coolflow 75 cooling/heating aggregate. The solutions were refreshed continuously $\left(0.91 \mathrm{~h}^{-1}\right.$ per aquarium) by means of multichannel peristaltic pumps. The composition of the solution was based upon the mean chemical composition of the waters in which $S$. aloides is encountered in the Netherlands (according to De 


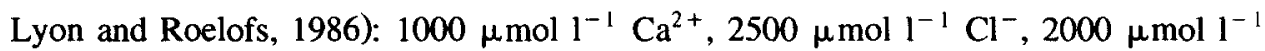
$\mathrm{Na}^{+}, 2000 \mu \mathrm{mol} \mathrm{l}^{-1} \mathrm{HCO}_{3}^{-}, 300 \mu \mathrm{mol} \mathrm{l}^{-1} \mathrm{Mg}^{2+}, 100 \mu \mathrm{mol} \mathrm{l}^{-1} \mathrm{SO}_{4}^{2-}, 110 \mu \mathrm{mol} \mathrm{l}^{-1}$ $\mathrm{K}^{+}, 10 \mu \mathrm{mol} 1^{-1} \mathrm{NO}_{3}^{-}$. Trace elements were added according to Roelofs (1991). Ammonium was added in the form of ammonium chloride in concentrations of $0,10,25$, $50,100,250 \mu \mathrm{mol} \mathrm{l}^{-1}$. The $\mathrm{pH}$ of the medium was set at 6.8 by adding hydrochloric acid. Cyanoguanidine $\left(0.5 \mu \mathrm{mol}^{-1}\right)$ was added to prevent nitrification of ammonium. The experiment was carried out with nine replicates for each ammonium concentration. Irradiance was provided through a photoperiod of $16 \mathrm{~h}$ at $220 \mu \mathrm{E} \mathrm{m}^{-2} \mathrm{~s}^{-1}$.

The concentrations in the aquaria were checked regularly and were never found to deviate more than $10 \%$ from the values mentioned above.

\subsection{Growth}

Every week the biomass of the plantlets was weighed after removing, very carefully, the adhering water and loosely adhering dead leaf material. After 13 weeks the plantlets were harvested. Analysis was carried out as described below.

\subsection{Nutrient and chlorophyll-a analysis}

The chemical composition of the plants was determined after destruction with sulphuric acid and hydrogen peroxide as described by Van Dijk and Roelofs (1988). The chlorophyll- $a$ content was also determined according to Van Dijk and Roelofs (1988). C and $\mathrm{N}$ analysis was carried out with the aid of a Carlo Erba CNS analyser. Destructions and CNS analysis were carried out on oven-dried green plant material $\left(48 \mathrm{~h}\right.$ at $\left.70^{\circ} \mathrm{C}\right)$.

\subsection{Free nitrogen containing compounds}

Free nitrogen containing compounds (NCC) (mainly amino acids) were determined according to the method described by Van Dijk and Roelofs (1988). Determinations were carried out on green, intermediately aged leaves which had been immediately frozen with liquid nitrogen and kept at $-40^{\circ} \mathrm{C}$ until analysis.

To check the extraordinarily high amino acid contents obtained in this experiment, a control experiment was carried with only a few plants at external ammonium concentrations of 50,100 and $250 \mu \mathrm{mol} \mathrm{I}^{-1}$. The results obtained revealed more or less the same concentrations of free amino acids as presented in Section 3.

\subsection{Plant and water layer analysis in Stratiotes stands}

During the summer of 1992 in 21 Stratiotes stands located in different parts of the Netherlands, young plantlets and water samples were collected. The nutrient levels in the plants were analysed as described by Van Dijk and Roelofs (1988). The water samples were analysed as described by Roelofs (1991).

\subsection{Calculations}

The amounts of nitrogen and carbon present in the different nitrogen or carbon containing fractions are calculated from the mean total $\mathrm{N}$ and mean total $\mathrm{C}$ concentra- 
tions detected with the CNS analyser and the mean concentrations of the different free nitrogen containing compounds (detected as described above).

\section{Results}

Table 1 shows the mean chemical composition of water samples and $S$. aloides plantlets collected in 1992 from 21 randomly selected stands. The results confirm that Stratiotes is confined to slightly eutrophic waters with a mean ammonium level of 7.8 $\mu \mathrm{mol} 1^{-1}$, a mean nitrate level of $6.8 \mu \mathrm{mol}^{-1}$ and a mean phosphate level of $1.8 \mu \mathrm{mol}$ $1^{-1}$. Furthermore, Table 1 shows the mean mineral content of young Stratiotes plants. These levels can be used as references for the values measured in the experiment.

Fig. 1 shows the growth curves of the plantlets at the different external ammonium levels. After 8 weeks the net growth was impaired at all external ammonium concentrations. Differences between the individual plants were considerable and, therefore, the mean final fresh weights (week 13) of the plants grown at $0,10,25$ and $50 \mu \mathrm{mol} \mathrm{l}^{-1}$ ammonium concentrations were not significantly different according to the $t$-test (Statistical Analysis Systems Institute Inc., 1985). The mean final fresh weights of plants grown at the 100 and $250 \mu \mathrm{mol} 1^{-1}$ ammonium concentrations, however, were significantly lower than at the other concentrations. Furthermore, large parts of the plants had become brownish in colour, particularly those grown at the higher external ammonium concentrations, indicating reduced vitality.

Potassium, magnesium and sodium levels were much higher in the plants that had been grown in the medium which contained only nitrate in comparison with plants from media containing ammonium (Table 2 ). In their natural environment, $S$. aloides plants normally contain high levels of potassium. The plants collected in the field (Table 1), for

Table 1

Nutrient levels in young plants and chemical composition of the water layer for 21 randomly chosen Stratiotes aloides stands in the Netherlands. Samples were collected in the summer of 1992. Nitrogen levels are detected in destruated samples. Min. is minimum value, Max. is maximum value. All values of the water samples are given in $\mu \mathrm{mol} \mathrm{l}^{-1}$ and values in plants in $\mu \mathrm{mol} \mathrm{g}^{-1} \mathrm{DW}$

\begin{tabular}{|c|c|c|c|c|c|c|}
\hline & \multicolumn{3}{|c|}{ Young plants } & \multicolumn{3}{|c|}{ Water layer } \\
\hline & $\overline{\text { Mean }}$ & Min. & Max. & Mean & Min. & Max. \\
\hline Nitrogen & 1251 & 628 & 1918 & & & \\
\hline Ammonium & & & & 7.8 & 4.1 & 23 \\
\hline Nitrate & & & & 6.8 & 0.8 & 89 \\
\hline Potassium & 1205 & 575 & 2162 & 147 & 20 & 461 \\
\hline Magnesium & 447 & 268 & 722 & 304 & 118 & 624 \\
\hline Calcium & 282 & 190 & 470 & 1088 & 169 & 2412 \\
\hline Phosphorus & 122 & 60 & 222 & 1.8 & 0.3 & 6.8 \\
\hline Iron & 6.8 & 0.7 & 31 & 6.0 & 1.0 & 12 \\
\hline Manganese & 26 & 4.8 & 58 & 1.5 & 0.1 & 15 \\
\hline Sodium & 303 & 87 & 612 & 1453 & 505 & 3042 \\
\hline
\end{tabular}




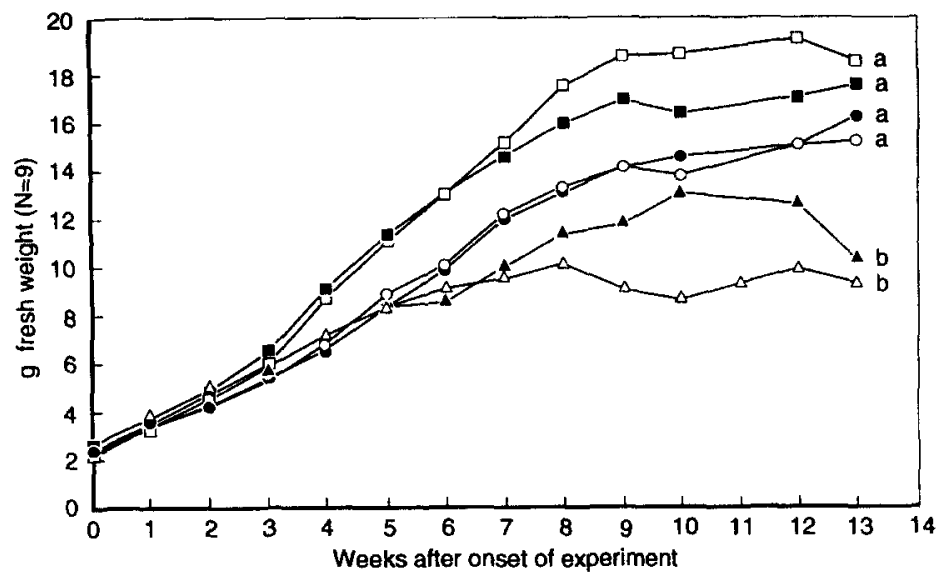

Fig. 1. Mean growth curves of young Stratiotes aloides plantlets at different extemal ammonium concentrations in a phosphate deficient medium $(N=9)$. Different characters indicate that the mean final fresh weights differed significantly $(P<0.05)$, according to the $t$-test. $\square, 50 \mu \mathrm{mol} 1^{-1}$ ammonium; $\square, 25 \mu$ mol $1^{-1}$ ammonium;, $10 \mu \mathrm{mol} \mathrm{l}^{-1}$ ammonium; $\bigcirc, 0 \mu \mathrm{mol} \mathrm{1^{-1 }}$ ammonium; $\wedge, 100 \mu \mathrm{mol} \mathrm{l}^{-1}$ ammonium; $\Delta, 250$ $\mu \mathrm{mol} \mathrm{^{-1 }}$ ammonium.

Table 2

Nutrient composition and chlorophyll-a levels of turions of Stratiotes aloides $\mathrm{L}$. at the onset of the experiment and plantlets after 13 weeks at different external ammonium concentrations. All values are given in $\mu \mathrm{mol} \mathrm{g}^{-1}$ DW except $C$ (mmol g-1 DW) and chlorophyll- $a\left(\mu g g^{-1}\right.$ FW). The standard deviation is given in parentheses $(N=9)$. All analyses were carried out in destruates except nitrogen (CNS) and carbon which were detected with a CNS analyser

\begin{tabular}{|c|c|c|c|c|c|c|c|}
\hline & \multicolumn{7}{|c|}{ Ammonium conc. in medium $\left(\mu \mathrm{mol}^{-1}\right)$} \\
\hline & Onset & 0 & 10 & 25 & 50 & 100 & 250 \\
\hline $\mathrm{C}$ & $\begin{array}{l}32.70 \\
(0.31)\end{array}$ & $\begin{array}{l}31.60 \\
(0.46)\end{array}$ & $\begin{array}{l}32.99 \\
(0.42)\end{array}$ & $\begin{array}{l}33.44 \\
(0.32)\end{array}$ & $\begin{array}{l}33.79 \\
(0.31)\end{array}$ & $\begin{array}{l}33.93 \\
(0.36)\end{array}$ & $\begin{array}{l}33.78 \\
(0.25)\end{array}$ \\
\hline N & $\begin{array}{c}2610 \\
(199)\end{array}$ & $\begin{array}{l}783 \\
(80)\end{array}$ & $\begin{array}{c}1622 \\
(171)\end{array}$ & $\begin{array}{c}1946 \\
(180)\end{array}$ & $\begin{array}{l}2199 \\
(201)\end{array}$ & $\begin{array}{l}2371 \\
(180)\end{array}$ & $\begin{array}{l}2405 \\
(194)\end{array}$ \\
\hline $\mathrm{N}(\mathrm{CNS})$ & $\begin{array}{c}3416 \\
(228)\end{array}$ & $\begin{array}{l}950 \\
(153)\end{array}$ & $\begin{array}{c}1957 \\
(189)\end{array}$ & $\begin{array}{l}2357 \\
(281)\end{array}$ & $\begin{array}{l}2550 \\
(92)\end{array}$ & $\begin{array}{l}2771 \\
(231)\end{array}$ & $\begin{array}{l}2800 \\
(210)\end{array}$ \\
\hline $\mathbf{P}$ & $\begin{array}{l}259 \\
(19)\end{array}$ & $\begin{array}{l}17.6 \\
(4.0)\end{array}$ & $\begin{array}{l}13.4 \\
(1.6)\end{array}$ & $\begin{array}{l}13.5 \\
(2.3)\end{array}$ & $\begin{array}{l}15.7 \\
(2.5)\end{array}$ & $\begin{array}{l}15.8 \\
(2.1)\end{array}$ & $\begin{array}{l}16.7 \\
(2.5)\end{array}$ \\
\hline K & $\begin{array}{c}1505 \\
(78)\end{array}$ & $\begin{array}{l}1007 \\
(205)\end{array}$ & $\begin{array}{l}577 \\
(55)\end{array}$ & $\begin{array}{l}496 \\
(61)\end{array}$ & $\begin{array}{l}503 \\
(50)\end{array}$ & $\begin{array}{l}455 \\
(51)\end{array}$ & $\begin{array}{l}505 \\
(88)\end{array}$ \\
\hline $\mathrm{Na}$ & $\begin{array}{l}142 \\
(41)\end{array}$ & $\begin{array}{l}120 \\
(28)\end{array}$ & $\begin{array}{l}64 \\
(25)\end{array}$ & $\begin{array}{l}51 \\
(14)\end{array}$ & $\begin{array}{l}48 \\
(17)\end{array}$ & $\begin{array}{l}49 \\
(19)\end{array}$ & $\begin{array}{c}44 \\
(18)\end{array}$ \\
\hline $\mathrm{Mg}$ & $\begin{array}{l}253 \\
(28)\end{array}$ & $\begin{array}{l}812 \\
(62)\end{array}$ & $\begin{array}{c}622 \\
(83)\end{array}$ & $\begin{array}{l}605 \\
(59)\end{array}$ & $\begin{array}{l}545 \\
(71)\end{array}$ & $\begin{array}{l}518 \\
(61)\end{array}$ & $\begin{array}{l}507 \\
(45)\end{array}$ \\
\hline $\mathrm{Ca}$ & $\begin{array}{l}172 \\
(7.2)\end{array}$ & $\begin{array}{l}220 \\
(35)\end{array}$ & $\begin{array}{l}196 \\
(39)\end{array}$ & $\begin{array}{l}191 \\
(27)\end{array}$ & $\begin{array}{l}202 \\
(26)\end{array}$ & $\begin{array}{l}194 \\
(29)\end{array}$ & $\begin{array}{l}181 \\
(14)\end{array}$ \\
\hline $\mathrm{Fe}$ & $\begin{array}{c}5.0 \\
(1.8)\end{array}$ & $\begin{array}{c}2.3 \\
(0.5)\end{array}$ & $\begin{array}{c}2.5 \\
(0.4)\end{array}$ & $\begin{array}{c}2.3 \\
(0.4)\end{array}$ & $\begin{array}{c}2.2 \\
(0.4)\end{array}$ & $\begin{array}{c}2.5 \\
(0.5)\end{array}$ & $\begin{array}{c}2.4 \\
(0.5)\end{array}$ \\
\hline Mn & $\begin{array}{l}12.6 \\
(5.0)\end{array}$ & $\begin{array}{c}9.2 \\
(1.9)\end{array}$ & $\begin{array}{c}7.0 \\
(1.3)\end{array}$ & $\begin{array}{c}7.9 \\
(1.5)\end{array}$ & $\begin{array}{c}8.2 \\
(1.5)\end{array}$ & $\begin{array}{c}8.2 \\
(2.1)\end{array}$ & $\begin{array}{c}9.4 \\
(1.8)\end{array}$ \\
\hline Chlor. $a$ & - & $\begin{array}{l}177 \\
(62)\end{array}$ & $\begin{array}{l}137 \\
(69)\end{array}$ & $\begin{array}{l}100 \\
(57)\end{array}$ & $\begin{array}{l}75 \\
(37)\end{array}$ & $\begin{array}{l}77 \\
(40)\end{array}$ & $\begin{array}{c}65 \\
(18)\end{array}$ \\
\hline
\end{tabular}


Table 3

Amounts of free amino acids and some other free nitrogen containing compounds (NCC) in the shoots of young Stratiotes aloides plants grown in a staged ammonium gradient for 13 weeks. All values are given in $\mu \mathrm{mol} \mathrm{g}^{-1} \mathrm{DW}$. Standard deviation is given in parentheses $(N=9)$. Numbers under the names of the NCC signify the $\mathrm{N}: \mathrm{C}$ ratio of the compound

\begin{tabular}{|c|c|c|c|c|c|c|}
\hline & \multicolumn{6}{|c|}{$\mathrm{NH}_{4}^{+}$conc. in medium $\left(\mu \mathrm{mol} \mathrm{l}^{-1}\right)$} \\
\hline & 0 & 10 & 25 & 50 & 100 & 250 \\
\hline Asparagine & 180.02 & 692.85 & 790.50 & 809.01 & 900.10 & 854.42 \\
\hline 0.50 & $(39.11)$ & $(108.99)$ & $(68.31)$ & $(150.01)$ & $(72.23)$ & $(40.50)$ \\
\hline Glutamine & 6.25 & 19.49 & 33.67 & 79.34 & 106.43 & 123.71 \\
\hline 0.40 & $(2.01)$ & $(5.15)$ & (9.91) & $(12.01)$ & $(18.16)$ & (15.11) \\
\hline Arginine & 5.78 & 18.51 & 32.86 & 48.92 & 69.34 & 77.45 \\
\hline 0.66 & $(2.00)$ & $(3.40)$ & $(8.11)$ & $(15.95)$ & (25.26) & (11.45) \\
\hline Serine & 5.53 & 21.68 & 31.25 & 44,00 & 68.59 & 75.92 \\
\hline 0.33 & $(2.23)$ & $(4.81)$ & $(8.21)$ & $(9.89)$ & $(14.01)$ & (9.29) \\
\hline Alanine & 2.93 & 10.66 & 14.63 & 34.04 & 42.95 & 50.11 \\
\hline 0.33 & $(0.79)$ & $(1.92)$ & $(2.22)$ & $(8.00)$ & $(10.11)$ & (11.01) \\
\hline Ethanolamine & 1.58 & 6.88 & 20.47 & 26.60 & 25.93 & 32.88 \\
\hline 0.50 & $(0.52)$ & $(1.40)$ & (7.12) & (6.88) & $(4.88)$ & $(8.12)$ \\
\hline Histidine & 2.22 & 5.17 & 7.08 & 13.00 & 13.85 & 21.66 \\
\hline 0.50 & $(0.67)$ & $(0.73)$ & (1.99) & (2.14) & (2.98) & (2.77) \\
\hline Aspartic acid & 3.73 & 9.00 & 10.27 & 12.16 & 13.93 & 15.35 \\
\hline 0.25 & $(0.81)$ & $(0.99)$ & $(1.30)$ & $(1.51)$ & $(1.77)$ & $(1.53)$ \\
\hline Tryptophan & 1.97 & 2.69 & 8.65 & 12.52 & 13.30 & 12.20 \\
\hline 0.18 & $(0.97)$ & $(1.04)$ & $(2.80)$ & $(2.12)$ & $(2.10)$ & $(1.08)$ \\
\hline Threonine & 1.89 & 5.98 & 6.87 & 8.68 & 11.80 & 9.85 \\
\hline 0.20 & $(0.50)$ & $(0.98)$ & $(1.00)$ & $(1.71)$ & $(2.41)$ & $(0.61)$ \\
\hline Valine & 1.44 & 3.58 & 4.78 & 8.14 & 8.85 & 8.57 \\
\hline 0.20 & $(0.34)$ & $(0.77)$ & $(0.80)$ & $(1.20)$ & $(1.22)$ & (1.11) \\
\hline Phenylalanine & 1.57 & 2.87 & 3.20 & 6.07 & 5.16 & 5.71 \\
\hline 0.11 & $(0.22)$ & $(0.70)$ & $(0.38)$ & $(1.15)$ & $(0.25)$ & $(1.01)$ \\
\hline Isoleucine & 1.64 & 4.01 & 4.41 & 6.14 & 5.82 & 5.40 \\
\hline 0.17 & $(0.53)$ & $(0.76)$ & $(0.90)$ & $(0.71)$ & $(0.77)$ & $(0.75)$ \\
\hline Glycine & 0.87 & 2.09 & 2.93 & 4.18 & 5.29 & 5.33 \\
\hline 0.50 & $(0.23)$ & $(0.55)$ & $(0.69)$ & $(0.80)$ & $(0.91)$ & $(0.99)$ \\
\hline G-amino but. ac. & 0.80 & 2.40 & 5.07 & 5.63 & 8.05 & 4.70 \\
\hline 0.25 & $(0.23)$ & $(0.88)$ & $(1.21)$ & $(1.33)$ & $(2.00)$ & $(1.08)$ \\
\hline Ornithine & 0.21 & 0.15 & 0.22 & 4.13 & 2.97 & 0.33 \\
\hline 0.40 & $(0.60)$ & $(0.41)$ & $(0.50)$ & (3.10) & $(1.90)$ & $(0.59)$ \\
\hline Lysine & 0.34 & 0.72 & 0.34 & 0.34 & 0.82 & 3.11 \\
\hline 0.33 & $(0.63)$ & $(1.50)$ & $(0.89)$ & $(0.95)$ & (1.32) & $(2.56)$ \\
\hline Leucine & 0.61 & 1.46 & 1.84 & 3.28 & 3.46 & 3.06 \\
\hline 0.33 & $(0.12)$ & $(0.33)$ & $(0.34)$ & $(0.50)$ & $(0.80)$ & $(0.51)$ \\
\hline Proline & ND & ND & 0.92 & 3.76 & 3.21 & 1.97 \\
\hline 0.20 & & & $(0.40)$ & $(0.99)$ & $(1.00)$ & $(0.40)$ \\
\hline Tyrosine & ND & ND & 0.27 & 2.68 & 2.51 & 1.88 \\
\hline 0.11 & & & $(0.46)$ & $(0.51)$ & $(0.61)$ & $(0.30)$ \\
\hline Ammonium & 12.20 & 14.12 & 20.07 & 39.82 & 100.84 & 111.29 \\
\hline & (3.42) & $(2.11)$ & $(4.85)$ & $(11.02)$ & $(25.63)$ & $(29.91)$ \\
\hline
\end{tabular}

ND, not detectable. 


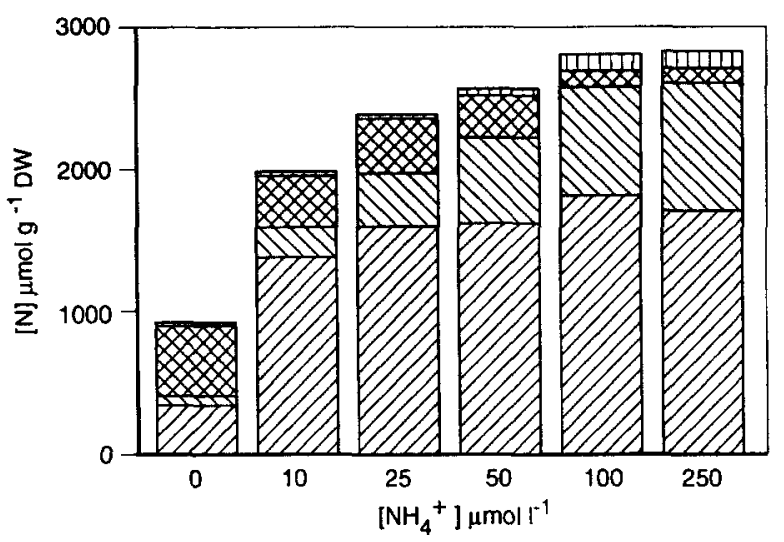

Fig. 2. Amount of nitrogen present in the different nitrogen containing fractions $(N=9)$. Hatching top right to bottom left, $\mathrm{N}$ fraction in free asparagine; hatching top left to bottom right, $\mathrm{N}$ fraction in other free nitrogen compounds; vertical lines, $\mathrm{N}$ fraction in free ammonium; cross-hatching, $\mathrm{N}$ fraction in other compound (including proteins).

instance, had a mean potassium concentration of $1205 \mu \mathrm{mol} \mathrm{1}^{-1}$ with the lowest potassium level encountered amounting to $575 \mu \mathrm{mol} \mathrm{l}^{-1}$ (Table 1). In the experiment, potassium levels were relatively low in the ammonium containing media and were lower than $500 \mu \mathrm{mol} \mathrm{g}^{-1}$ DW at external ammonium levels higher than $25 \mu \mathrm{mol}^{-1}$.

$\mathrm{P}$ levels were extremely low at all ammonium concentrations (Table 2). Chlorophyll- $a$ levels also strongly decreased as external ammonium levels increased (Table 2).

$\mathrm{N}$ levels in plants were very high, and at external ammonium concentrations higher than $25 \mu \mathrm{mol} \mathrm{l}^{-1}$, exceeded $2000 \mu \mathrm{mol} \mathrm{g}^{-1}$ (DW). Only in the medium without ammonium were $\mathrm{N}$ levels in the plants relatively low; however, levels were still higher

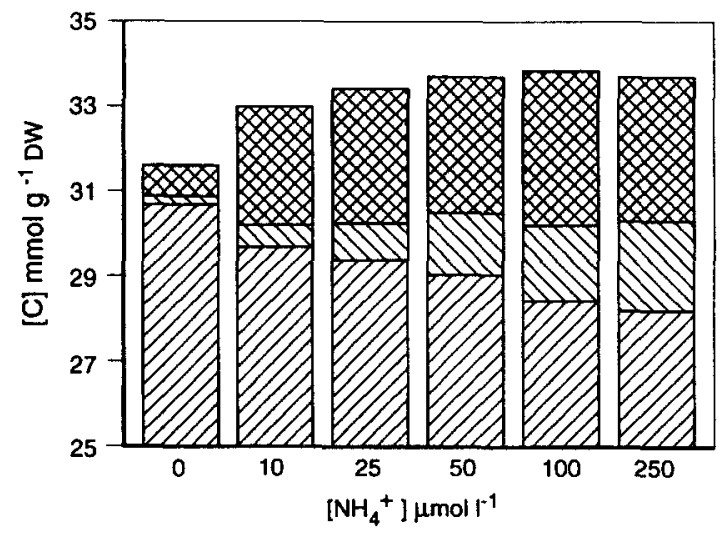

Fig. 3. Amount of carbon present in the different carbon containing fractions $(N=9)$. Cross-hatching, $\mathrm{C}$ fraction in free asparagine; hatching top left to bottom right, $\mathrm{C}$ fraction in other free nitrogen compounds; harching top right to bottom left, $\mathrm{C}$ fraction in other compounds. 
than the lowest concentrations found in young Stratiotes plants from the field (Table 1). $\mathrm{N}$ levels measured with the CNS analyser were higher than values obtained by the conventional destruction method. Although the latter technique obviously leads to some nitrogen losses, the results obtained with this method are presented because the field data were obtained with this method. The differences between the results of the two methods were larger as $\mathrm{N}$ levels in the shoots were higher (Table 2). The $\mathrm{N}$ levels in the turions were high (Table 2). This, however, is normal and not due to high ammonium levels in the water layer or to mineral deficiencies.

Table 3 shows the results of the analyses of free NCC (i.e. mainly amino acids). Asparagine appears to be by far the dominant constituent in the free NCC pool. Increasing external ammonium levels led to strongly raised levels of asparagine and almost all other free NCC. Proline and tyrosine were only detected at external ammonium concentrations higher than $10 \mu \mathrm{mol} \mathrm{1^{-1 }}$. Fig. 2 shows that most of the nitrogen in the plantlets was present as free NCC. Only in the plantlets from the medium that contained only nitrate is more than $50 \%$ of the nitrogen present in other compounds. At the two highest ammonium concentrations, almost all nitrogen is present as free NCC. Higher external ammonium concentrations do not lead to increased levels of asparagine. Glutamine, arginine, serine and alanine are responsible for the increased free NCC levels. Free ammonium was present in the plants at all concentrations (Table 3, Fig. 2), but increased strongly with the external ammonium concentration.

Fig. 3 shows that the fraction of $\mathrm{C}$ present as free NCC increases strongly when ammonium levels increase. Total $\mathrm{C}$ concentrations also increase upon increased external ammonium levels, but this increase is not sufficient to meet the $\mathrm{C}$ demand necessary for the incorporation of $\mathrm{N}$ into NCC. As a result, the amount of $\mathrm{C}$ present in compounds other than free NCC decreased considerably with increasing external ammonium concentrations.

\section{Discussion}

The free amino acid concentrations and particularly the asparagine and glutamine levels in the plantlets were extremely high (Table 3, Fig. 2). In the ammonium-containing media up to $82-97 \%$ of total nitrogen in the plantlets was present as free amino acids, of which asparagine was by far the most abundant. Even without external ammonium, almost half of the total nitrogen content of the phosphorus deficient plants was present as free amino acids. The free amino acid levels are extremely high and, as far as we know, have seldom been found before in any other species. Prianischikov (1922, cited in Webster, 1959) found that seedlings of barley and pea germinated in a $0.1 \%$ ammonium chloride solution, accumulated almost all nitrogen as free asparagine. High values have also been recorded for phosphorus deficient Citrus trees (ca $50 \%$ of total $\mathrm{N}$ as free NCC) (Achituv and Bar-Akiva, 1973), and old sulphur deficient alfalfa leaves (up to $86 \%$ of total $\mathrm{N}$ as free NCC) (Mertz and Matsumoto, 1956).

As at the end of the experiment the phosphorus levels in the plantlets were extremely low, the growth retardation that could be observed after 9 weeks, at all ammonium 
concentrations, is undoubtedly caused by phosphorus deficiency. The relative shortage of one or more minerals is well known to lead to increased accumulation of free amino acids (Holley and Cain, 1955; Rabe, 1990; Ericsson et al., 1993). Achituv and Bar-Akiva (1973) and Rabe and Lovatt (1986) showed that phosphorus deficiency and consequential growth retardation leads to a strong accumulation of arginine in Citrus sp. and Cucurbita pepo L. They concluded that growth retardation leads to a concomitant surplus of ammonium in the shoots which is detoxified by the formation of NCC.

Increased free NCC levels are thought to lead to decreased protein synthesis because energy is diverted to the energy intensive NCC synthesis (Mertz et al., 1952; Rabe, 1990). As phosphate is important for the transfer of energy within the cells and especially for the synthesis of RNA, which is in turn essential for the synthesis of proteins (Marschner, 1986), it is supposed that (extreme) P limitation can also affect the synthesis of proteins in a more direct way.

Decreased protein and increased NCC levels can also be caused by increased protein breakdown. In general, stress can lead to increased protein breakdown, probably because the membranes of the organelles containing proteolytic enzymes become permeable (Davis, 1982). Dissimilation of proteins can generate energy for more basal metabolic processes (Webster, 1959; Marschner, 1986). Ammonium liberated during this dissimilation will be incorporated into asparagine or other free NCC (Webster, 1959). However, we were not able to distinguish between the different processes (impaired protein synthesis versus increased protein breakdown) that may cause decreased protein and increased free NCC levels, as found in our experiment.

In general, the plantlets which were growing in ammonium containing media were not vital. Many (older) leaves died and were lost during the experiment as is most clearly reflected by the decrease in biomass at $100 \mu \mathrm{mol} \mathrm{l}^{-1}$ ammonium. At external ammonium concentrations of 100 and $250 \mu \mathrm{mol} \mathrm{1^{-1 }}$ the mean final fresh weights were significantly lower when compared with the mean final fresh weights at the other concentrations. The amount of nitrogen incorporated in non-free NCC was very low. It is striking that the synthesis of free NCC is very effective even at the stage in which almost all nitrogen in the plants is present as free NCC. This seems to confirm that the detoxification of ammonium is vital for the survival of the plants. Ammonium, however, did accumulate in the 100 and $250 \mu \mathrm{mol} \mathrm{I}^{-1}$ treatments in particular, indicating that at these concentrations the capacity of the plants to detoxify ammonium has reached its upper limits.

Furthermore, NCC accumulation appears to be an important C-consuming process. Increased nitrogen levels in the plants lead to increased $\mathrm{C}$ levels but this increase is insufficient to compensate for the $\mathrm{C}$ necessary for NCC synthesis under $\mathrm{P}$ limited conditions. Increased NCC synthesis is an important sink for the $\mathrm{C}$, assimilated by the plants, and as a consequence there is less $\mathrm{C}$ available for other (structural) compounds such as chlorophyll- $a$. This is clearly reflected by the decreasing chlorophyll- $a$ contents with increasing external ammonium levels. Increased $\mathrm{N}$ accumulation also decreases the C:N ratio of Stratiotes plants. McMahon et al. (1974) stated that a $\mathrm{C}: \mathrm{N}$ ratio lower than 17 is required by herbivores in order to prefer plants as their food source. In our experiments, the plants from the medium that contained only nitrate had a $\mathrm{C}: \mathrm{N}$ ratio of 33.2. However, the plants from the media with $10,25,50,100$ and $250 \mu \mathrm{mol} \mathrm{l}^{-1}$ 
ammonium had $\mathrm{C}: \mathrm{N}$ ratios of $16.9,14.2,13.3,12.2$ and 12.1 respectively. Thus, nitrogen accumulation, may make the Stratiotes plants attractive for herbivores and pathogenic microorganisms. In the field we have observed that particularly the young parts of the plants and the young tillers and turions are eaten by waterfowl such as swans (personal observations). In some stands in early April, only very few tillers and turions remained, although plenty of stalks were found to which tillers and turions, had previously been attached.

Ammonium is well known to decrease the uptake of other cations (Marschner, 1986). Indeed in our experiment potassium, magnesium and sodium levels decreased as ammonium levels increased (Table 2). In particular, the potassium and sodium levels in the ammonium fed plantlets are low compared with the levels encountered in the field (Table 1).

Stratiotes is generally found in slightly eutrophic waters with moderate levels of $P$ and relatively low levels of ammonium. At present in the Netherlands, nitrogen is almost always present in sufficient amounts due to the high nitrogen load resulting from agricultural practices and industrial emissions. However, Stratiotes is seldom found in waters in which ammonium levels increase to values well above $50 \mu \mathrm{mol} \mathrm{l}^{-1}$. Table 1 shows that the mean ammonium concentration in the natural environment amounts to 7.8 $\mu \mathrm{mol} 1^{-1}$. Smolders and Roelofs (1993) found that since $1980 \mathrm{~S}$. aloides had disappeared from many locations where the ammonium concentration had increased to values higher than $30 \mu \mathrm{mol} 1^{-1}$. Cultivation of mature Stratiotes plants for a period of 10 weeks in a staged ammonium gradient (Roelofs, 1991) revealed that an increase of ammonium levels from 10 to $50 \mu \mathrm{mol}^{-1}$ did lead to a strong decrease in the vitality of $S$. aloides plants; more than $80 \%$ of the leaves became brown and necrotic within the cultivation period. The mechanism described in this article may also have been involved in the die-back of mature Stratiotes plants as described by Roelofs (1991).

The results reveal the mechanism involved in the decline of $S$. aloides plants under $P$ limited conditions, and can at least partly explain why $S$. aloides is rarely found in waters with very low $\mathrm{P}$ levels and/or increased ammonium levels. As the young Stratiotes turions are not yet rooting in the substrate, they are totally dependent on the uptake of phosphate from the water layer. In waters with very low $\mathrm{P}$ levels, the turions are destined to become phosphorus deficient, and hence, more susceptible to ammonium toxicity.

It is concluded that, like other plants (Marschner, 1986), Stratiotes cannot exclude ammonium. At the very least this is true when growth is limited due to mineral deficiencies. In such a scenario, the nutritional status of the plants is strongly influenced by increased ammonium uptake. Apparently, phosphorus deficient plants are neither able to prevent ammonium uptake sufficiently nor to divert energy from the NCC synthesis to protein synthesis as long as external ammonium levels are high. As a result, leaf dieback occurs due to nutritional imbalances, decreased net protein synthesis and the accumulation of toxic ammonium. Finally, this will lead to a strongly reduced vitality (or even death of the plants) and to an increased susceptibility to herbivory and/or pathogens. Apart from the other hazards that endanger Stratiotes stands, such as sulphide toxicity (affecting the roots), eutrophication and iron deficiency (Roelofs, 1991; Smolders and Roelofs, 1993), ammonium toxicity can, particularly in combination with 
one of the other hazards, lead to the decline of Stratiotes as has been observed in many parts of the Netherlands in recent decades.

\section{Acknowledgements}

The authors wish to thank Mrs. B. Lebbink, Mr. M. van Aaken, Mr. M. van der Gaag and Mrs M.C. van Riel for technical assistance and Mrs. G.M. van Gestel for critically reading the manuscript.

\section{References}

Achituv, M. and Bar-Akiva, A. (1973) Nitrogen accumulation induced by phosphorus deficiency in citrus plants, Sci. Hortic., (Vol. 1), 251-262.

Davis, D.D., 1982. Protein degradation under stress. In: D. Boulter and B. Parthier (Editors), Nucleic Acids and Proteins in Plants 1: Structure, Biochemistry and Physiology of Proteins. Springer, Berlin/Heidelberg/New York, 445 pp.

De Lyon, M.J.H. and Roelofs, J.G.M., 1986. Aquatic macrophytes in relation to water quality and sediment characteristics, parts I and II. Department of Aquatic Ecology, University of Nijmegen, 323 pp. (In Dutch.)

Ericsson, A., Norden, L.G., Näsholm, T. and Walheim, M. (1993) Mineral nutrient imbalances and arginine concentrations in needles of Picea alba (L.) Karst. from two areas with different levels of airbome deposition, Trees, (Vol. 8), 67-74.

Holley, R.W. and Cain, J.C. (1955) Accumulation of arginine in plants affected with iron-deficiency type chlorosis, Science, (Vol. 121), 172-173.

Lorentz, H. (1975) Free amino acids in tomato plants in relation to form and concentration of nitrogen in the rooting medium, Plant Soil, (Vol. 45), 163-168.

Magelhaes, J.R. and Wilcox, G.E. (1984) Growth, free amino acids and mineral composition of tomato plants in relation to nitrogen form and growing media, J. Am. Soc. Hortic. Sci., (Vol. 109), 406-411.

Marschner, H., 1986. Mineral Nutrition of Higher Plants. Academic Press, London, 674 pp.

McMahon, R.F., Hunter, R.D. and Russell-Hunter, W.D. (1974) Variation of Aufwuchs at six freshwater habitats in terms of carbon biomass and of carbon:nitrogen ratio, Hydrobiologia, (Vol. 45), 391-404.

Mertz, E.T. and Matsumoto, H. (1956) Further studies on the amino acid and proteins of sulfur-deficient alfalfa, Arch. Biochem. Biophys., (Vol. 63), 50-63.

Mertz, E.T., Singleton, V.L. and Garey, C.L. (1952) The effect of sulfur on the amino acids of alfalfa, Arch. Biochem. Biophys., (Vol. 38), 139-145.

Näsholm, T. and Ericsson, A. (1990) Seasonal changes in amino acids, protein and total nitrogen in needles of fertilized Scots pine trees, Tree Physiol., (Vol. 6), 267-281.

Näsholm, T., Edfast, A.B., Ericsson, A. and Norden, L.G. (1994) Accumulation of amino acids in some boreal plants in response to increased nitrogen availability, New Phytol., (Vol. 126), 137-143.

Rabe, E. (1990) Stress physiology: The functional significance of the accumulation of nitrogen-containing compounds, J. Hortic. Sci., (Vol. 65), 231-243.

Rabe, E. and Lovatt, C.J. (1986) Increased arginine biosynthesis during phosphorus deficiency, Plant Physiol., (Vol. 81), 774-779.

Roelofs, J.G.M. (1991) Inlet of alkaline river water into peaty lowlands: effects on water quality and Stratiotes aloides L. stands, Aquat. Bot., (Vol. 39), 267-293.

Rotsnitschek-Schimmel, I. (1985) Seasonal dynamics of nitrogenous compounds in a nitrophilic weed: II The role of free amino acids and proteins as nitrogen store in Urtica dioica, Plant Cell Physiol., (Vol. 26), $177-183$.

Smolders, A. and Roelofs, J.G.M. (1993) Sulphate-mediated iron limitation and eutrophication in aquatic ecosystems, Aquat. Bot., (Vol. 46), 247-253. 
Statistical Analysis Systems Institute Inc., 1985. SAS User's Guide: Statistics, Version 5 edn. SAS Institute Inc., Cary, NC, USA.

Tromp, J. and Ovaa, J.C. (1979) Uptake and distribution of nitrogen in young apple trees after application of nitrate or ammonium, with special reference to asparagine and arginine, Physiol. Plant., (Vol. 45), 23-28.

Van Dijk, H.F.G. and Roelofs, J.G.M. (1988) Effects of excessive ammonium deposition on the nutritional status and condition of pine needles, Physiol. Plant., (Vol. 73), 494-501.

Vines, H.M. and Wedding, R.T. (1960) Some effects of ammonia on plant metabolism and a possible mechanism for ammonia toxicity, Plant Physiol., (Vol. 35), 820-825.

Webster, G.C., 1959. Nitrogen Metabolism in Plants. Row, Peterson and Company, Evanston, IL, 152 pp. 